|Araştırma Makalesi / Research Article |

\title{
Okul Öncesi Öğretmenlerinin Erken Çocukluk Döneminde Uygulanan Standart Testlerle ilgili Görüşlerinin İncelenmesi
}

\section{Investigation of Preschool Teachers' Opinions About Standard Tests Applied in Early Childhood}

\section{Eda Bayraktaroğlư ${ }^{1}$, Derya Neval AYEKiN DÜLGER ${ }^{2}$}

\author{
Anahtar Kelimeler \\ 1. Okul öncesi \\ 2. Erken çocukluk \\ 3. Değerlendirme \\ 4. Standart test \\ 5. Formal değerlendirme
}

\section{Keywords \\ 1. Preschool \\ 2. Early childhood \\ 3. Assessment \\ 4. Standard test \\ 5. Formal assessment}

Başvuru Tarihi/Received 18.07.2019

Kabul Tarihi /Accepted 07.11.2020
Öz

Okul öncesi öğretmenlerinin erken çocukluk döneminde uygulanan standart testlere ilişkin görüşlerinin belirlenmesi amacıyla yapılan bu çalışma nitel bir araştırmadır. Araştırma, ulaşılabilir örneklem yoluyla belirlenen 4'ü özel, 11'i devlet okulunda görev yapan toplam 15 okul öncesi öğretmeniyle derinlemesine görüşme yöntemi kullanılarak gerçekleştirilmiştir. Araştırmada, veri toplama aracı olarak açık uçlu sorulardan oluşan yarı yapılandııılmış görüşme formu kullanılmıştır. Görüşme formundaki açık uçlu sorulara verilen cevaplar içerik analizi tekniği ile değerlendirilmiştir. Öğretmenlerin erken çocukluk döneminde uygulanan standart testlere ilişkin görüşleri ile ilgili bulgular derinlemesine incelenmiş belirlenen kodlar dört temel tema çerçevesinde sunulmuştur. Çalışmanın bulguları, okul öncesi öğretmenlerinin çocukların gelişimlerini takip etmede standart testleri kullanmadıklarını, daha çok gözlem metodunu kullandıklarını, gelişimsel değerlendirmeye yeterince vakit ayırmadıklarını ve bunun bilgi eksikliğinden kaynaklandığını göstermiştir. Bu nedenle araştırma sonuçları ışı̆ıında, öğretmenlere ve öğretmen adaylarına değerlendirme konusunda eğitim verilmesi önerilmektedir.

\section{Abstract}

This study, which was conducted to determine the opinions of preschool teachers about the standard tests applied in early childhood, is a qualitative research. The research was carried out using indepth interview method with a total of 15 preschool teachers working in 4 public and 11 public schools determined by accessible sample. In this study, semi structured interview form consisting of open ended questions was used as data collection tool. The data of the study were analyzed using the content analysis method. The findings of the study showed that preschool teachers did not use standardized tests to follow the development of their students, used more observation methods, did not spend enough time to develop a developmental assessment and this was due to lack of knowledge. The findings regarding the opinions of the teachers regarding the standard tests applied in the early childhood period were examined in depth and the codes determined were presented within the framework of four basic themes. Therefore, in the light of the results of the research, it is recommended that teachers and teacher can didates should be given training on assessment.

\footnotetext{
${ }^{1}$ Pamukkale Üniversitesi, Acıpayam Meslek Yüksekokulu, Çocuk Bakımı ve Gençlik Hizmetleri Bölümü, Denizli, TÜRKiYE; https://orcid.org/0000-0002-7287-3260 2 ilke Çocuk Evi, Denizli, TÜRKiYE; https://orcid.org/0000-0002-6285-1949
} 
Extended Abstract

\section{Introduction}

Early childhood assessment provides benefits to teachers, school administrators and parents who practice the program to recognize and support their children more effectively. Considering the effect of early childhood on the learning experiences in other periods of the child's life, it is necessary to evaluate the development of the children according to their level of development with the appropriate measurement tools in order to be able to support their development in the most appropriate way during this period and to provide the early possible detection of possible problems. A lasting impact on children's cognitive development, personalities and social behaviors depends on interventions in early childhood (Bredekamp, 2015; UNICEF, 2003). When the relevant field is examined, it was observed that there were limited number of studies related to the qualification, the frequency and manner of assessment and assessment of preschool teachers who took an active role in raising the individuals of the future. In the light of this information, it is considered that it is very important to determine which standard tests the preschool teachers use as an assessment tool, and at what intervals they use these tests and the standard tests applied in early childhood.

In this study, it is aimed to examine the opinions of preschool teachers about the standard tests applied in early childhood. Within the scope of this basic objective; The aim of this study is to answer the basic problems such as how the preschool teachers think about the necessity of assessment in early childhood, whether they use standardized tests for developmental assessment, how often they follow developmental screening, and how they make developmental assessments of students with special needs.

\section{Method}

This study was designed as a case study which is a qualitative research method. The study group was chosen from the classroom teachers in accordance with the homogeneous sampling method from the criterion sampling methods. In the study, Personal Information Form and a semistructured interview form that is suitable for qualitative research consisting of openended questions were used as the data collection tool. The analysis of the answers to the openended questions in the interview form was evaluated using "descriptive analysis", one of the qualitative data analysis methods.

\section{Result and Discussion}

Findings about the opinions of teachers about the standard tests applied in early childhood; It is presented within the framework of three basic themes: The opinions of preschool teachers about children's development follow-up roller, ler The opinions of preschool teachers on standard tests "and leri The opinions of preschool teachers on the follow-up of the development of their students". The interviews revealed that teachers preferred to make more observations to follow their students' progress. In the expression of very few teachers, the expression of development retardation was in order not to miss the critical period. Participant teachers evaluate the development of their students; they have felt feelings like responsibility, happiness, curiosity and excitement. This study shows that teachers do not have enough time to follow the progress of their students and do not understand its importance. However, it is understood from the statements of the teachers that children do not have enough knowledge about how to follow their progress. The interviews with the teachers revealed that the standard tests and the purpose of their use are not fully known but the names of some tests are known. When the teachers' standard tests were not used in developmental assessment, when the interview data were examined, it was found that these trainings were used in some provinces and because they were paid, it was found that the standard test was not used because the standard tests did not fit our culture. Although teachers have different opinions about the duration of follow-up of their students, it can be said that the majority have the right information about the development follow-up time. Participant teachers, however, strongly attribute the link between the educational objectives and developmental assessment. According to the teacher expressions, it is possible to say that the teachers do not determine the students with special needs, they do not use standard tests, they do not know how to evaluate the students with special needs, and they think that it is more appropriate for the students to make their development assessments by the experts themselves.

In summary, the results of this study showed that teachers did not devote enough time to developmental assessment and this was due to lack of knowledge. Therefore, in the light of the results of the research, it is recommended that teachers be given training on assessment. The combination of different methods of development assessment makes a significant contribution to identifying children with special needs. It is recommended to raise awareness of the ways in which children with special needs should be identified. To ensure this, teachers can be informed about the importance of development assessment and standardized tests in preschool education institutions. In addition, experts may record and publish online videos on the subject. In this way, teachers should be told about the necessity of regular developmental assessment of children. 
GiRiş

Erken çocukluk eğitiminde değerlendirme, gelişimsel çerçevede ele alınan, çocuğun gelişimini tanımlamak için kullanılan bir kavramdır (Işıkoğlu Erdoğan ve Canbeldek, 2017). Bir çocuğun gelişiminin en üst düzeye ulaşmasının sağlanması için ilk ve en önemli adım, çocuğun gelişimini doğru yaklaşımlar ile değerlendirmektir (Karaaslan, 2016). Erken çocukluk döneminde 'değerlendirme' ye yönelik tanımlar incelendiğinde birçok farklı görüşle karşılaşılsa da değerlendirme; bireyi tanımak, özel durumlarını, ihtiyaçlarını tespit etmek, gelişim ve öğrenme sürecine katkı sağlamak, bireyin kendi farkındalığını kazandırmak ve bireye uygun olanaklar sunmak için çeşitli kaynaklardan bilgi edinme ve bir yargıya varma süreci olarak özetlenebilir (Özkan, 2015).

Etkili öğrenme sürecinin en önemli aşaması olan değerlendirme konusu gün geçtikçe önem kazanmaktadır. Öğretmenin görevini etkili bir şekilde yürütebilmesi çocuğu tanıyıp objektif olarak değerlendirmesine bağlıdır. Çünkü öğrenme ve öğretme süreçlerinde öğrencilerin anlama düzeylerini ve bilgi oluşturma becerilerini öğretmenlere açık bir şekilde yansıtan en önemli etmen değerlendirme aşamasıdır (Ay, 2015). Değerlendirme aşamasındaki süreç ile çocuğun gelişim alanları ile ilgili sürekli ve ayrıntılı bilgi sahibi olunur (Önder, 2016) ve öğretmen bu değerlendirme sürecinin sorumluluğunu taşır (Mcafee ve Leong, 2012). Öğretmen çocukları hazırladığı değerlendirme planına göre gözler, gerekli verileri toplar, özetler ve değerlendirir (Tuğrul, 2005). Çocukların gelişimindeki ilerleme ya da sapmaları ölçerek aileleri de çocuk hakkında bilgilendirir (Can Gül, 2009). Öğretmenin eğitim süreci sonunda, planladığı hedeflere ulaşmış olması gerekir. Öğretmenler eğitim planlarını düzenlemek, uygulamak, öğrencilerinin ihtiyaçlarını ve öğretim programlarının etkililiği belirlemek amacıyla da değerlendirmelerde bulunurlar (Ay, 2015). Değerlendirme aşamasının, diğer süreçlere de yol gösterici özelliği olması nedeniyle özenle uygulanması gerekir (Sezer, 2010).

Öğretmenler belirledikleri hedefler doğrultusunda planlar hazırlayarak eğitim faaliyetlerini yürütürler. Bu eğitim faaliyetleri içerisinde önemli yer tutan değerlendirme süreci çocukların gelişimini ve eğitimi destekler (Parlakyıldız ve Yıldızbaş, 2007). Eğitimin başında, süreç içinde ve sonunda yapılan değerlendirme, programın ve eğitsel hedeflerin de ne ölçüde gerçekleştirildiğinin göstergesidir (Deniz Kan, 2007). Çocuğun bir şeyi yapabilme kapasitesi bilinmelidir. Çocuklar yapar, ancak çocuğun gerçekleştirilmeyen görevleri gerçekleştirme kapasitesi bilinmediğinden doğru bir şekilde değerlendirme yapılamayabilir (Lidz, 2003). Aslında değerlendirme "çocuklar ne biliyor ve ne yapabilir?" sorularının cevaplarına dair her çeşit ölçme yöntemi ve aracına işaret etmektedir (Mcafee ve Leong, 2012). Öğrencinin hazırbuluşluk düzeyinin belirlenmesi ile eğitim ortamı ve yönteminin, personelin yetkinliğinin belirlenmesi sağlanacaktır. Değerlendirmede bu çeşitliliğin her kademedeki eğitim için olması gerekir, ama erken çocukluk eğitiminde bir zorunluluktur. Çünkü okul öncesi dönem gelişimde kritik dönemlerdendir. Çocuğun gelecekteki öğrenme süreçleri için temel oluşturmaktadır (Tunçeli ve Zembat, 2017). Çocuğu tanıma ve değerlendirme, erken çocukluk döneminde çocukların güçlü ve gelişmeye açık veya zayıf yönlerinin belirlenmesi, desteklenmesi gereken özel ihtiyaçlarının doğru zamanda ve doğru yönlendirmelerle karşılanmasına olanak sağlar. Çocuklara kendilerini keşfetmesine fırsat yaratılması, bireysel ve sosyal duyarlılıklarının geliştirilmesi ve çocuğun kendi hakkında öz kontrol becerisinin gelişmesinin sağlaması için de değerlendirme süreci oldukça önemlidir (Can Gül, 2009). Tüm gelişim basamaklarının temeli olan erken çocukluk dönemi ile ilgili yapılan araştırmalar insan beynini erken deneyimlerin şekillendirdiğini ve bu deneyimlerin yaşam boyu süren etkisini vurgulamaktadır (Karaaslan, 2016). Bu dönemde elde edilen yanlış ve yetersiz değerlendirme sonuçları, gelişimin erken dönemde, uygun şekilde desteklenme fırsatının kaçırılmasına neden olurken; çocuklarla ilgili verilecek kararlar, uygulanacak etkinlikler ve alınacak önlemler onların sonraki dönemlerini daha sağıılı bir şekilde geçirmelerini sağlayacaktır (Özkan, 2015).

Erken çocukluk döneminde değerlendirme, programın uygulayıcısı olan eğitmenlere hatta okul idaresine ve ebeveynlere, çocuklarını daha iyi tanıma ve destekleme için ve rakamsal bilgi toplama, erken çocukluk eğitimi kurumlarındaki diğer çocuklara veya toplumsal değerlere göre çocuğun seviyesini belirleme, bireysel farklılıklarını ölçme gibi çocuğu daha iyi tanıyabilme konusunda yardımcı olur (Can Gül, 2009). Gelişimin tanımında, takip eden yaş dönemi özelliklerine doğru bir ilerleme beklenir. Gelişim dönemlerinde farklı riskler ve kolaylaştırıcılar ile karşılaşıldığından, değerlendirmenin aralıklı olarak tekrarlanması, beklenen ilerlemenin olup olmadığının belirlenmesi gerekir. Ancak, erken çocukluk döneminde gelişim değerlendirmesi, bu yaş grubuna özel yeterlilik de gerektirir. Gelişimi değerlendiren uzmanlar; gelişimi izlemeli, çocuğun işlevselliğine ve en üst düzeydeki gelişimine olumsuz etki edebilecek riskleri erken dönemde belirlemeli, risklerin çözümüne yönelik destekler konusunda bilgi sahibi olmalı ve ilerlemenin devam etmesi için nasıl destekleyebilecekleri konusunda aileye rehberlik etmelidirler (Karaaslan, 2016). Yani öğretmenler değerlendirme aşamasının sorumluluğu ile değerlendirmeye özgü profesyonel sorumluluğu da üstlenmelidir (Mcafee ve Leong, 2012). Erken çocukluk dönemi çocuklarının hızlı gelişim göstermeleri nedeniyle de doğru değerlendirme çok önemlidir. (Deniz Kan, 2007).

Okul öncesi dönemde, ölçme ve değerlendirme kavramları çocukların doğal yaşamlarının bir unsuru olarak ele alınmalıdır (Işıkoğlu Erdoğan ve Canbeldek, 2017). Değerlendirme süreci aşamalı devam etmesi nedeniyle, süreci bölen bir uygulama olmaması oldukça önemlidir. Çocukların günlük yaptıkları materyaller değerlendirme aracı olarak kullanılmalı ve değerlendirme sürecinde çocuklara yer almalıdır (Deniz Kan, 2007). Çünkü okul öncesi eğitimde önemli olan sonuç değil süreçtir. Bu nedenle de sürecin çok yönlü olarak değerlendirilmesi gerekmektedir (Can Gül, 2009).

Çocukların gelişimleri ile ilgili geçerli ve güvenilir bilgiler elde etmek ve çocukların tüm gelişim alanları ile ilgili doğru değerlendirmeler yapmak için verilerin ev, okul farklı ortamlardan, oyun alanları gibi doğal anlardan toplanması gerekir. Bu gereklilik çocukların değerlendirilmesinde kullanılabilecek farklı yaklaşım ve araçlara dikkati çekmektedir (Işıkoğlu Erdoğan ve Canbeldek, 2017). Bu yaklaşımlar formal, informal ve alternatif değerlendirme başlıkları altında toplanabilir. Formal değerlendirme, daha önceden hazırlanmış bir süreci takip eden özel olarak oluşturulmuş araçları kullanan bir değerlendirme tü rü (Tunçeli ve Zembat, 2017) iken informal değerlendirme, günlük rutinlerin içinde yer alan gözlem, görüşme ve deneyimleri içeren

| Kastamonu Eğitim Dergisi, 2020, Vol. 28, No. 6| 
değerlendirme türüdür (Özkan, 2015). Alternatif değerlendirmede ise çocuklar izlenir, materyal örnekleri alınır, uygulamalar oyun temellidir. Çocukların kendi bilgi düzeyleri ve yeteneklerine göre performanslarını gösterebilecekleri doğal ve anlamlı faaliyetler yapmaları sağlanarak yapılan değerlendirmedir (Işıkoğlu Erdoğan ve Canbeldek, 2017).

Çocuğu tanımayı ve eğitim ortamına yerleştirmeyi sağlayan formal değerlendirme, çocukların farklı gelişim alanlarında, kendi yaş grubundaki çocuklarla karşılaştırıldığında ne durumda olduğunu belirler. Formal değerlendirme aracı olarak genellikle standart testler kullanılır (Yılmaz Topuz, 2015). Bu testler; yapılış şekli ve değerlendirme kriterleri daha önceden belirlenmiş olan çocukların ortak koşullarda, ortak işler verilerek değerlendirildiği testlerdir (Blake ve Wise, 2014; McAfee ve Leong, 2012). Temelde bir çocuğun gelişimini benzer özelliklerdeki başka çocuklarla kıyaslar (Beaty, 2018). Erken çocukluk döneminde, çocukların gelişim düzeylerini, öğrenme sorunlarını ve seviyelerini tespit etmeye yarayan, tüm çocuklara uygulanabilen gelişimsel tarama testlerine; çocukların okul için gerekli hazırbulunuşluk düzeylerini belirleyerek, bir üst kademeye geçmesine karar verilen hazırbulunuşluk testlerine; gelişimsel tarama testleri sonuçlarına göre tekrar değerlendirilmesi ve müdahale planı oluşturulması için tanı konulması gereken çocuklar için tanılayıcı testler gibi standart testlere rastlanır. Bu testlere şu örnekleri vermek mümkündür: Metropolitan okul olgunluğu ve brainline okula hazırbulunuşluk testi, Gazi Erken Çocukluk Değerlendirme Aracı, Ankara Gelişim Tarama Envanteri, Marmara Gelişim Ölçeği, Denver II Gelişimsel Tarama Testi; Gessell, Bayley Testi, Peabody Resim Kelime Testi. Ayrıca ülkemizde okul öncesi eğitiminde kullanımı çok tercih edilmeyen bunun yanı sıra diğer ülkelerde sıklıkla kullanılan başarı testleri ve yetenek testleri de vardır (Işıkoğlu Erdoğan ve Canbeldek, 2017).

Erken çocukluk döneminde değerlendirme yöntemlerine ilişkin görüşler incelendiğinde formal değerlendirme yöntemi ve standart testlerin kullanılmasının tartışmalı bir konu olduğu göze çarpar. İnformal değerlendirme sürecinde öğrencilerin davranışları, sözlü sözsüz iletişimleri, yazılı notlar ve resimleri gibi öğrencilerle ilgili her türlü bilgi değerlendirme için kullanılacak veri niteliğindedir. Bu nedenle bazı kaynaklar çocukların içinde bulunduğu dönem ve gelişim özellikleri göz önünde bulundurulduğunda informal değerlendirmeye, formal değerlendirmeye göre daha çok yer verilmesi gerektiğini belirtir (Özkan, 2015). Hatta standart testlerle ilgili çocukların aynı testi farklı zamanlarda cevapladıklarında tutarlı cevaplar vermemeleri, birçok testin akademik performansın ancak çeyreğinden biraz fazlasını gösterdiği ve çocukların bazen 'bilmiyorum' derken aslında 'yapmak istemiyorum' demek istedikleri gibi sınırlılıklarına dikkat çeker (Beaty, 2018). Diffily (1994) erken çocukluk dönemi eğitimcilerinin değerlendirmeye yönelik inanış ve uygulamalarını incelediği araştırmasında, öğretmenler standart testlere karşı negatif görüş bildirmişlerdir ve bu testlerin çocuklar için uygun olmadığını belirtmişlerdir. Ancak çocukların nasıl ve ne derece gelişip olgunlaştığını bilmenin yanında, çocukların gelişim ve öğrenmesinde bir problem olup olmadığını da bilmeye ihtiyacımız vardır. Erken çocukluk döneminde değerlendirme; çocuğun akademik becerileri hakkında bilgi edinmek, çocuğun sağlık açısından tanılanması, çocuğun gelişiminde bir gecikme olup olmadığı, erken çocukluk eğitimi programlarının özel eğitimle desteklenip desteklenmeyeceği ve program geliştirmek amacı ile de yapılmaktadır. Yani erken çocukluk döneminde değerlendirmenin amaçları arasında özel öğrenme veya gelişimsel gereksinimi olan çocukların belirlenmesi de yer alır (Tunçeli ve Zembat, 2017). Erken çocukluk dönemindeki çocukların uzun süreli gelişimlerini sağlamak, gelişim geriliği yaşayan çocukları tespiti etmek ve erken müdahale programı oluşturmak önemlidir (Kahraman, Ceylan ve Korkmaz, 2016).

Okul öncesi dönemdeki çocuklarla çalışan bir öğretmen gelişim takibi yapabilmek ve en üst seviyede eğitimini desteği yapabilmek için standart testler gibi bazı araçlar kullanmalıdır (Kahraman, Ceylan ve Korkmaz, 2016). Özellikle gelişmekte olan ülkelerde çocuğun bakımını üstlenen kişiler gelişim ile ilgili yeterli bilgi düzeyinde olmayabilirler. Bu nedenle gelişimin değerlendirilmesinde standart araç kullanılması gelişmiş ülkelerle karşılaştırıldığında daha fazla önem taşımaktadır (Karaaslan, 2016). Standartlaştırılmış testler, çocukların zamanla karşılaştırılmasını sağlar, tipik gelişmeden sapmanın derecesini belirlemek için bir temel sağlar (Bondurant-Utz ve Luciano, 1994). Gelişimsel geriliği veya özel gereksinimi olan çocukları belirlemek için gelişimsel tarama testleri ya da tanılayıcı testler kullanılır. Bu testler yetersizlik veya öğrenme güçlüğü riski bulunan çocukların belirlenmesinde ilk adımı oluşturur (Tunçeli ve Zembat, 2017). Yapılan araştırmalara göre, herhangi bir test kullanılmadan sadece klinik tespit ile gelişme geriliği tespit oranının \%30, test kullanılarak ise \%70-80 çıkarılabildiğini göstermiştir (Demirci ve Kartal, 2012). Ancak kullanılacak standart testlerin yüksek geçerlilik ve güvenliğe sahip olanların tercih edilmesi bununla birlikte öğretmenin testi nasıl kullanacağı ve sonuçları nasıl değerlendireceği konusunda eğitim alması gerekmektedir (Can Gül, 2009). Buna paralel olarak Sezer (2010), okul öncesi öğretmenlerinin ölçme ve değerlendirmeyi kullanma düzeylerini belirlemek için yaptığı çalışmada, çalışmaya katılan öğretmenlerden standart testleri kullandıklarını belirtenlerin, standart testleri her yaş grubu için ayrı hazırlanması, programın geliştirilmesinde yol gösterici rol oynaması, çocuğun güçlü ve zayıf yönlerini ortaya çıkarması gibi özelliklerinden dolayı tercih ettiklerini belirlemiştir. Bu çalışmaya katılan öğretmenlerden standart testleri kullanmadıklarını belirtenlerin, geçerlik ve güvenirliği yüksek test bulmak zor olması, testleri uygulamanın uzun zaman ve uzmanlık gerektirmesi gibi nedenlerle kullanmadıklarını belirlemiştir. Ayrıca okul öncesi eğitim programı incelendiğinde değerlendirme yöntemlerinin nasıl uygulanacağı ve örneklerinin verildiği ancak standart test olarak herhangi bir örneğin sunulmadığı dikkati çeker (Sezer, 2010). Şıvgın (2015), yaptığı çalışmasında öğretmenlerin tekniklerin örneklerini yetersiz bulduğu sonucuna ulaşmıştır.

Toplumumuzun en az \%10’unu özel gereksinimi olan bireyler oluşturmaktadır ve ülkemizde bu alanda yapılan araştırmalar çocukluk dönemini kapsamakta yetersizdir. Gelişimsel zorlukları olan çocukların toplumun \%10-16’sından az olmadığı tahmin edilebilir. Özellikle erken çocukluk döneminde gelişimsel testler uygulanırken bilişsel gelişimin çeşitli alanları incelenmeli ve klinik tespitler, aile görüşleri, standardize edilmiş psikometrik ölçümler gibi farklı yöntemler birlikte kullanılmalıdır. Genellikle okul öncesi dönemdeki çocuklarda; \%5-10 oranında dil gelişimi sorunu, \%8 öğrenme güçlüğü sorunları, \%1-1.5 bilişsel sorunlar görülür. (Karaaslan, 2016). Tarama testlerinden kimileri çocukların gelişimlerini bir bütün halinde değerlendirirken, kimileri de sadece 
çocukların dil gelişimlerini değerlendirmektedir. Çocuğun akran ilişkilerini ve kendini tanıyarak bireyselleşmesini sağlayan dil çocuğun gelişiminde en önemli basamaklardan biridir (Crain ve Lillio Martin, 1999; Davies, 2010), Erken tanı ve müdahale için çocukların yaşamları boyunca gelişim değerlendirmesi yaptırmaları önerilmektedir. Öncelikle 0-6 ay arasında bebekler bir kez mutlaka gelişimsel taramadan geçmelidir, daha sonra ise en az 12-18 ay, 2-3 yaş ve 5-6 yaş arasında çocukların gelişimsel değerlendirmeleri yapılmalıdır (Madan ve Tekin, 2015).

Erken çocukluk döneminde çocukların gösterdikleri hızlı gelişimden dolayı aileler, öğretmenler ve eğitimciler çocukların gelişim süreçleri ile daha fazla ilgilenmeye başlamışlardır. Bu değişime bağlı olarak sadece birkaç tane olan değerlendirme araçlarının da sayısı artmıştır (Demircan ve Olgan, 2011). Davranış değerlendirme ölçekleri, görsel algı testleri, performans envanterleri, portfolyo, benlik kavramına ilişkin araçlar, sosyometrik testler, video ve ses kayıtları bunlardan sadece bazılarıdır (Beaty, 2018). Okul öncesi çocukları tanımada kullanılan bilimsel ölçme araçlarından çocukların gelişimsel özelliklerine uygun olanını seçmek, doğru değerlendirme uygulamaları yapmak öğretmenler için zor olabilmektedir (Özkan, 2015). Öğretmen aile iş birliğine yönelik (Işık, 2007; George, 2012) ailelerin öğretmenlerle iletişim süreçleri, ailelerin beklentileri ve iletişim süreçlerinde karşılaştıkları zorlukların incelendiği araştırmada öğretmenler 'ailelerin değerlendirme sürecinde görünür olmadığını' belirtilmiştir (Mehlig, 2013).

Ölçme ve değerlendirme araçlarından bazıları da uzmanlık gerektirdiğinden okul öncesi öğretmenleri tarafından kullanılamamaktadır (Yılmaz Topuz, 2015). Çünkü okul öncesi öğretmenleri ancak ölçme ve değerlendirme konusunda yeterli eğitimi alır ve edindikleri deneyimi etkin bir şekilde kullanabilirlerse ölçme ve değerlendirme işlemlerini nesnel ve güvenilir bir şekilde yapabilirler. Erken çocukluk dönemindeki çocuklarla çalışan öğretmenler ölçme ve değerlendirme yöntemlerini kullanırken, yeterli bilgi, beceri ve tutuma sahip olurlarsa eğitim açısından olumlu çıkarımlar olacaktır (Çakan, 2004). Bu öğretmenlerin ölçme ve değerlendirme yapabilme hususunda yeterli bilgiye sahip olmaları için yüksek öğretim kurumlarından mezun olmadan önce iyi bir eğitim almış olmaları ve meslek hayatlarında hizmet içi eğitim kurslarına katılmaları gerekir (Erdemir, 2007).

Erken çocuklukta değerlendirme, programı uygulayan öğretmenlere, okul yöneticilerine ve anne babalara, çocukları daha etkin bir şekilde tanıma ve destekleme konusunda yararlar sağlar. Erken çocukluk dönemi çocuğun yaşamının diğer dönemlerindeki öğrenme yaşantılarına etkisi düşünüldüğünde, bu dönemde gelişiminin en uygun şekilde desteklenebilmesi ve olası mümkün sorunların erken tespiti ile gerekli erken müdahalelerde bulunulabilmesi için çocukların içinde bulundukları gelişim düzeyine uygun ve doğru ölçme araçlarıyla değerlendirilmesi gereklidir. Çocukların bilişsel gelişimleri, kişilikleri ve sosyal davranışları üzerinde kalıcı bir etki yaratılması erken çocukluk döneminde yapılacak müdahalelere bağlıdır (Bredekamp, 2015; UNICEF, 2003). ilgili alan yazın incelendiğinde geleceğin bireylerinin yetiştirilmesinde etkin görev alan olan okul öncesi öğretmenlerinin ölçme ve değerlendirme ile ilgili yeterlilik, uygulama sıklığı ve şekli, tutum ve görüşleri ile ilgili Ülkemizde yapılan çalışmaların sınırlı sayıda olduğu gözlenmiştir (Deniz Kan, 2007; Demirci ve Kartal, 2012; Yılmaz Topuz, 2015; Kahraman, Ceylan ve Korkmaz, 2016; Işıkoğlu Erdoğan ve Canbeldek, 2017; Yiğit, Özyurt ve Adıyaman, 2019). Bu bilgiler ışığında okul öncesi öğretmenlerinin değerlendirme aracı olarak hangi standart testleri kullandıkları, bu testleri hangi aralıklarla kullandıkları gibi erken çocukluk döneminde uygulanan standart testler ile ilgili görüşlerinin belirlenmesinin oldukça önemli olduğu düşünülmektedir.

\section{Araştırmanın Amacı ve Problemi}

Bu çalışmada okul öncesi öğretmenlerinin standart testlere ilişkin görüş ve uygulamalarının incelenmesi amaçlanmaktadır. Bu temel amaç kapsamında; okul öncesi öğretmenlerinin gelişimsel değerlendirmede standart testlerden hangi şekilde yararlandıkları, kullandıkları standart testlerin neler olduğu, standart testleri kullanma amaçları ve özel gereksinimi olan çocukların değerlendirilmelerinde standart testlerin uygulanması ile ilgili görüşlerinin ve uygulamalarının incelenmesi amaçlanmıştır.

\section{YÖNTEM}

\section{Araştırmanın Modeli}

Bu araştırmada, okul öncesi öğretmenlerinin erken çocukluk döneminde uygulanan standart testlere ilişkin görüşlerini belirlemek amacıyla nitel durum araştırma yöntemi kullanılmıştır. Nitel araştırmacılar, insanların deneyimlerini nasıl yorumladıklarını, nasıl bir anlam yüklediklerini anlamaya ve anlatmaya çalışırlar (Merriam, 2015). Nitel araştırma, olayları ve olguları doğal ortamları içinde betimlemeye, katılımcıların bakış açılarını anlamaya ve yansıtmaya dayalı bir yaklaşımıdır (Yıldırım ve Şimşek, 2006).

\section{Katılımcılar}

Katılımcılar rastlantısal olmayan örnekleme türlerinden biri olan uygun veya elverişlilik (convenience) örnekleme türü ile belirlenmiştir. Bu tür örnekleme, araştırmaya hız kazandıran bir yöntemdir. Çünkü bu yöntemde araştırmacı, yakın ve erişilmesi kolay olan bir durumu seçer. Bu örnekleme yöntemi çoğu zaman araştırmacının diğer örnekleme yöntemini kullanma olanağının olmadığı durumlarda kullanılır (Kılıç, 2013). Denizli il merkezinde uygun örnekleme yöntemiyle 15 okul öncesi öğretmeni seçilmiştir.

Araştırmaya katılan öğretmenlerin demografik özellikleri incelendiğinde 7'sinin 25-35 yaş aralığında (\%46,6), 6'sının 36-45 yaş aralığında (\%40), 2'sinin 46-55 yaş aralığında (\%13,3) olduğu görülmektedir. Öğretmenlerin 13'ü lisans (\%86,6), 2'si ise yüksek 
lisans (\%13,3) mezunudur. Katılımcılardan 3'ü 1-5 yıl (\%20), 4'ü 6-10 yıl (\%26,6), 4'ü 11-15 yıl (\%26,6), 2'si 16-20 (\%13,3) ve 2'si 21 yıl ve üstü $(\% 13,3)$ mesleki kıdeme sahip olduklarını belirtmişlerdir.

\section{Veri Toplama Araçları}

Araştırmanın verileri yarı yapılandırılmış derinlemesine görüşmeler aracılığı ile toplanmıştır. Bu amaçla standart testlerle ilgili açık uçlu sorulardan oluşan yarı yapılandırılmış görüşme formu araştırmacılar tarafından hazırlanmıştır. Görüşme formunda yer alan sorular hazırlanmadan önce, araştırma içeriği ile ilgili ulusal ve uluslararası alan yazın taraması yapılmıştır. Daha sonra görüşme formda yer almasına karar verilen sorular seçilerek yarı yapılandırılmış görüşme formu oluşturulmuştur. Oluşturulan görüşme formunun amacı ve kapsamı açısından değerlendirmesini yapmak ve geçerliğini sağlayabilmek için 4 akademisyenden görüş alınmış daha sonra 12 sorudan oluşan yarı yapılandırılmış görüşme formu geliştirilmiştir.

\section{Verilerin Toplanması}

Araştırmacılar öğretmenlere yapılan çalışmanın amacı ve içeriği hakkında bilgiler vermiştir. 15 öğretmen ile 40-60 dakika arasında süren bireysel derinlemesine görüşmeler yapılmıştır. Yapılan görüşmelerin ses kaydı alınarak daha sonra yazıya dönüştürülmüştür. Görüşmelerde öğretmenlere kişisel bilgileri sorulduktan sonra "Kaç yıldır öğretmenlik mesleğini yapıyorsunuz ve en son hangi okuldan mezun oldunuz? Öğrencilerinizin gelişimlerini takip etmek istediğiniz bir günde neler yaparsınız anlatır mısınız? Erken çocukluk döneminde çocukların gelişimleri sizce neden takip edilmelidir? Öğretmenlik mesleğiniz boyunca sınıfınızda tanısı konulmuş özel gereksinimli bir öğrenciniz oldu mu? Standart testler nedir tanımlar mısınız? Standart testlere örnek verir misiniz? Standart testlerle ilgili görüşleriniz nelerdir? Gelişim testlerini uygularken neler hissediyorsunuz? Bir veli sınıfına gelerek çocuğuna herhangi bir test uygulanmasını istemediğini söyledi. Bu durumda ona ne cevap verirsiniz? Sizce ideal öğretmen gelişim testlerini hangi sıklıkla uygular? Eğitim hedefleri ve gelişimin değerlendirmesi arasındaki bağı nasıl yorumlarsınız? Okulunuzda çocuk gelişimi uzmanı, rehber öğretmen veya psikolog var mı? Okullarda standart testleri kimlerin uygulaması gerektiğini düşünüyorsunuz?" şeklinde yarı yapılandırılmış sorular yöneltilmiştir.

\section{Verilerin Analizi}

Verilerin analizinde içerik analizi tekniği kullanılmıştır. İçerik analizi, birbirine benzeyen verileri belirli kavramlar ve temalar çerçevesinde bir araya getirerek okuyucunun anlayabileceği bir biçimde yorumlamaktır. İçerik analizinde, toplanan verileri açıklamaya yardımcı olacak kavramlara ve ilişkilere ulaşmak için özetlenen ve yorumlanan veriler, derinlemesine işlenerek yeni kavramlara ulaşılır (Yıldırım ve Şimşek, 2006).

Bu çalışmada veriler dört aşamada analiz edilmiştir:

1. Verilerin kodlanması; veriler okunarak kodlar belirlenmiştir.

2. Kodlanan verilerin temalarının belirlenmesi; derinlemesine görüşme sorularına verdikleri cevaplara dayalı olarak temalar oluşturulmuştur.

3. Kodlar ve temalar düzenlenmiştir.

4. Bulgular temalar doğrultusunda tanımlanmış ve yorumlanmıştır.

\section{BULGULAR}

Öğretmenlerin erken çocukluk döneminde uygulanan standart testlere ilişkin görüşleri ile ilgili bulgular derinlemesine incelenmiş; "Formal değerlendirme yöntemleri, informal değerlendirme yöntemleri, kritik dönem, gelişimin takibi, sorumluluk, mutluluk, merak, heyecan, GEÇTA, Metropolitan, Portage, portfolyo, yetenek, başarı testi, eğitim ücreti, eğitimde yeri, e-okul, rehber öğretmen, çocuk gelişimi uzmanı, okul öncesi öğretmeninin sorumluluğu" şeklinde kodlar belirlenmiştir. Belirlenen kodlar bu çalışmada dört temel tema çerçevesinde; "Neden ve nasıl değerlendiriyorum?", "Ne hissediyorum?”, "Standart testlerle ilgili ne düşünüyorum?" ve "Bana düşen görev nedir?" sunulmuştur.

\section{Neden ve Nasıl Değerlendiriyorum?}

Bulguların derinlemesine incelenmesiyle belirlenen; formal değerlendirme yöntemleri, informal değerlendirme yöntemleri, kritik dönem, gelişimin takibi kodları “Neden ve nasıl değerlendiriyorum?” teması başlığı altında toplanmıştır. Yapılan görüşmelerde okul öncesi eğitimi öğretmenleri çocukları değerlendirmenin önemli olduğunu vurgulamışlardır. Öğretmenlerin erken çocukluk döneminin yaşamın kritik bir dönemi olması sebebiyle çocukların değerlendirilmelerinin gerekli olduğunu ifade etmişlerdir. Örneğin katılımcı bir öğretmen aşağıdaki ifadeleri ile çocukları değerlendirmenin önemini net bir şekilde açıklamıştır.

"Ağaç yaşken eğilir, çünkü kişilik gelişimi ve zekâ gelişimi erken çocukluk döneminde büyük önem taşır, büyük bölümü erken çocukluk döneminde gelişir. Gelişimleri ile ilgili sorunlar önceden tespit edilmeli. Gelişim dönemlerine uygun özelliklere mi sahipler; eksiklik ve farkındalıklarını ileriki dönemler için önemli bunlar. Çocuk büyüdüğünde sorun yaşamasın diye takip edilmeli(Ö7)."

Yukarıdaki ifadelerde Öğretmen 7, erken dönemde çocukların gelişim özelliklerinin bilinmesinin sorunların önceden çözümlenmesi adına önemli olduğunu vurgulamaktadır. Gelişimsel olarak önemli değişimlerin meydana geldiği erken çocukluk 
döneminde gelişimin mutlaka takip edilmesinin çocuğun yetişkinliğe doğru gelişim süreci için kritik olduğu aşağıdaki öğretmen ifadelerinde bir kez daha vurgulanmıştır.

"Erken çocukluk dönemi önemli, bir fiziksel, bilişsel, sosyal ve duygusal gelişim dönemidir ve bu dönemde, tüm bu alanlarda ömür boyu sürecek gelişimin temeli atılacağı ve çok önemli kısmı çocuk tarafından kazanılacağı için, erken çocukluk dönemi gelişim açısından son derece önemlidir ve mutlaka takip edilmelidir. Gelişim özelliklerinin eksik olması farklı açılardan sorun olduğunun göstergesi olabilir çünkü kritik dönemler var. Gecikirsek telafisi olmuyor (Ö13)."

Görüşme sonuçların hemen hemen tüm öğretmenlerin değerlendirmenin önemini dile getirdiklerini göstermektedir. Çocukları değerlendirme için hangi araçları kullandıkları sorulduğunda gözlemin en fazla tercih edilen araç olduğu ortaya çıkmıştır. Özellikle çocukların serbest oyunda gözlemenin onları değerlendirme en etkili yol olduğu “Öğrencilerime sınıfça paylaşım gerektiren oyunlar oynatırım. Bunun sebebi çocukların oyun oynamalarını sağlayarak, kendi aralarında oynarken daha rahat gözlem yapmam. Oyun içerisinde nasıl davrandıklarını gözlemler not alırım (Ö3)" ifadeleri ile açıkça dile getirmiştir.

Serbest oyunun yanı sıra, günlük planları içerisinde yer verdikleri etkinliklerde veya sohbet sırasında çocukları değerlendirdiklerini belirten bir öğretmen; "Küçük kas gelişimlerini kontrol etmek istediğim bir günde öğrencilerim için hareketli etkinlikler ve zihinsel etkinlikler planlarım. Onların bunları yapıp yapamama durumlarına göre değerlendirme notları tutarım(Ö8)." Bu ifadesiyle, öğretmen değerlendirme amaçlı etkinlikler planladığını ve notlar aldığını belirtmiştir.

Değerlendirmede gözlemin yanı sıra görüşme ve değerlendirme formlarını kullandıklarını ifade eden öğretmenlerde olmuştur. Örneğin, Öğretmen 2 “Öğrencilerimin gelişimlerini takip etmek istediğim zaman, daha önce onlara öğretmiş olduğum kavram, bilgi ya da konu hakkında sorular yöneltirim. Konularla ilgili onlara vermiş olduğum bilginin kalıcılık ve kazanım durumunu genellikle soru cevap yöntemi ile değerlendiririm" diyerek çocuklarla görüşmeler yaptığını dile getirmiştir. Bir diğer öğretmen ise; "Internetten bulduğum genel bir değerlendirme formu var. Onu uyguluyorum. Tüm gelişim alanları ile ilgili sorular var. Oyun gözlem formu gibi formlarda var ama onları kullanmıyorum, içeriğinde lego köşesi, oyuncak köşesi gibi sorular içeriyor. Çocuklar artık o köşelerde oynamıyor daha çok dramatik oyun oynuyorlar. O yüzden beğenmedim(Ö10)." ifadesiyle çocukların gelişimlerini değerlendirmek için değerlendirme formlarını kullanmayı tercih ettiğini belirtmiştir. Bu formlar arasında kendine göre kullanışlı olanları tercih ettiğini vurgulamıştır.

Görüşmeler sırasında okul öncesi öğretmenleri çocukları değerlendirirken standart testler, süre kaydı, işaret listesi, alternatif değerlendirme araçları gibi farklı değerlendirme araçlarını kullandıklarından söz etmemişlerdir. Dile getirilmeyen bu değerlendirme araçlarını öğretmenlerin çocukları tanıma ve değerlendirmede kullanmadıkları söylenebilir.

\section{Ne Hissediyorum?}

Bulguların derinlemesine incelenmesiyle belirlenen; sorumluluk, mutluluk, merak, heyecan kodları “Ne hissediyorum?” teması başlığı altında toplanmıştır. Katılımcı öğretmenler çocukları değerlendirirken; sorumluluk, mutluluk, merak ve heyecan gibi duyguları hissettiklerini belirtmişlerdir. Örneğin; “Erken tanı ve tedavi önemli olduğu için gelişim testlerini çok önemsiyorum. Öğrencinin gelişim gösterdiği, basamakları çıktığı durumlarda mutlu oluyorum (Ö15). Öğrencilerin farklılıklarını ortaya çıkarmalarına bir fırsat tanıyacağı için bu uygulamalar bende merak ve heyecan yaratıyor (Ö2)."

Yukarıda belirtilen ifadelerden öğretmenlerin çocukların gelişimlerini değerlendirirken çocukların ilerleme gösterdiklerini gördüklerinde olumlu duygular hissettikleri anlaşılmaktadır. Aşağıdaki ifadede öğretmen 7 çocukların gelişimlerini değerlendirirken yaşadığı olumsuz duyguları şu şekilde anlatmıştır:

En yoğun hissettiğim duygu sorumluluk duygusu oluyor. Atladığım şeyler olduğunu test yaparken fark ediyorum. Kesin yaparlar diye düşünüyorum örneğin düz çizgide yürür. Bir öğrencim yapamadı. Ailesi ile görüştüm. Tekstilde işçi annesi orada başına bir şey gelmesin diye hep yürütece koymuşlar çocuğu, beş yaşında basmayı bilmiyor, hep parmak ucunda yürüyor. İlgili aile çocuktaki eksikleri tespit edip söylüyor. Öğretmen o zaman eksiği hemen tespit ediyor, dezavantajlı bölgede okula gönderiyorum ya daha ne yapayım diyor. Çocuktaki eksikleri söylediğinizde taktı bu öğretmen benim çocuğuma diyor. Sen boş ver benim çocuğum iyi diyor. Öğretmende bu sefer bir şey söylemek ilgilenmek istemiyor (Ö5)." Bu ifadeyle, öğretmenin çocukların gelişimlerini takipte sorumluluk duygusunu kendisinde hissettiği fakat ailelerden de gelişim geriliğinin tespiti konusunda destek beklediği anlaşılmaktadır.

\section{Standart Testlerle İgili Ne Düşünüyorum?}

Bulguların derinlemesine incelenmesiyle belirlenen; GEÇTA, Metropolitan, Portage, portfolyo, yetenek, başarı testi, eğitim ücreti, eğitimde yeri, e-okul kodları "Standart testlerle ilgili ne düşünüyorum?" teması başlığı altında toplanmıştır. Öğretmenlerle yapılan görüşmeler, standart testlerin ne olduğunun ve kullanım amacının tam olarak bilinmediğini fakat bazı testlerin isimlerinin bilindiğini ortaya koymuştur. Öğretmen ifadelerinde standart testlerden Gazi Erken Çocukluk Değerlendirme Aracı (GEÇTA)'ya, Denver'a, Metropolitan Okul Olgunluğu Testine ve Portage testine rastlanmıştır.

"Standart testler performans ve davranış testleri olarak genel anlamda ikiye ayrılır. Hiç uygulamadım ama biliyorum. Standart testler tüm çocuklara uygulanan klasik testlerdir. Çocuğun gelişim özelliklerinin taraması amaçlanır. Standart test verileri değerlendirilerek çocuğun gelişimi ile ilgili fikir edinilir. Bunlardan bazılarının metropolitan okul olgunluğu testi, gazi erken çocukluk değerlendirme aracı, portage. Bir de denver vardı onun gibi. Benim hiç sertifikam yok. Duygusal zekâ testleri de var (Ö12).” 
“Genel yetenek testleri belirli düzeylerde bireyin genel zihin yeteneklerini; özel yetenek testleri, müzik, resim gibi alanlarda öğrencinin sahip olduğu özel zihin yeteneklerini; farklı yetenek testleri de dil yeteneği, soyut kavrama gibi farklı zihin yeteneklerini ölçmek amacıyla hazırlanmıştır(Ö8)."

Yukarıdaki öğretmen ifadelerinden anlaşılacağı üzere öğretmenlerin standart testlerin ne olduğu ile ilgili net bir bilgisi olmamakla birlikte akıllarında kalan genel bilgilere rastlanmaktadır. Öğretmenler standart olmayan bazı başka testleri standart test olarak dile getirmişlerdir. Örneğin katılımcı bir öğretmen; "Standart testler rehberlik ve araştırma tarafından çocuğa uygulanması önerilmiş testlerdir. Bireylerin hepsine uygulanabilen bir testtir. Yetenek, başarı, ilgi testleri olabilir, bu konuda bilgim yok (Ö2)." şeklinde ifadelerinde standart testlerin ne olduğunun bilinmediği görülmektedir.

Benzer şekilde başka bir öğretmen; “Özel merkezlerde doktorların uyguladıkları testler. Doktorlar dışında uygulanması çok büyük zarar verebilir çocuğa. Doktorlar çocukların gelişimlerinde bir aksilik görürlerse bu testi uygularlar. Neler olduklarını bilmiyorum. Kişilik testi ve davranış testi olabilir. Bu çocuğun gelişimine göre değişir (Ö9)." ifadesiyle standart testlerin ne olduğunun ve kullanım amacının tam olarak bilinmediği görüşüne örnek oluşturmaktadır.

Öğretmenlerin standart testleri neden gelişim değerlendirmede kullanmadıklarında ilişkin görüşme verileri incelendiğinde, bu eğitimlerin belirli illerde ve paralı olduğu için, öğrencilere standart testi uygulamanın uzun süreceği için, bazı ifadelerde ise standart testlerin kültürümüze uymadıkları için kullanılmadığı görüşlerine rastlanmıştır.

"Bu testler doğru uygulandığında öğrenci ile ilgili çok olumlu. Zaman zaman çocuklara bu tür testlerin uygulanması onların gelişimlerini görmek için yararlı olabilir. Çocuğu tanımak için doğru yorum yapmak için fırsat veriyor ama eğitim her şehirde olmuyor. Ben mezun olduğumdan beri Denizli'de çalışıyorum. Burada böyle bir eğitim yok. Büyükşehirlere gitmek zor. Bir de paralı olduklarını biliyorum. Bu yüzden hiç almayı düşünmedim (Ö13)."

Yukarıdaki katılımcı öğretmen ifadesinden standart test eğitimi almak isteyen öğretmenlerin eğitim yeri ve ücreti nedeniyle almadıkları anlaşılmaktadır.

“Öğrencilerin hepsine aynı testi uygulayarak karşılaştırılmalarına çok karşıyım. Her bireye farklı test uygulanmalıdır. İhtiyacı olan çocuklara uygulanmalıdır. İhtiyacı olmayan bir çocuğa böyle testleri uygulamaya gerek yok bence. Sınıfımda ben zaten kimin ihtiyacı var kimin yok bunu anlayabilirim. Diyelim ki bilişsel olarak geri olduğunu düşünüyorum o zaman ona göre bir şey uygular bakarım. Bu standart testler hepsine aynı soruyu soruyor. Bu doğru olmaz (Ö10)."

Çalışmaya katılan öğretmenlerden her çocuk için farklı bir test olması gerektiği, bazı çocuklar için ise gerek olmadığı görüşüne sahip olan bir öğretmen; yukarıdaki şekilde görüşünü ifade ederek, standart testlerin neden kullanılması gerektiğine dair öğretmenlerin bilgisi olmadığına dair bir örnek olmuştur. "Milli, kültürel, sosyal açıdan milletimize uygun testler konusunda sıkıntı olduğunu düşünüyorum. Standart testler başka kültürlere ait geliyor bana. Bizi yansıtmıyor o testleri bizim milletimizin çocuklarına uygulayıp doğru cevaplar alacağımızı düşünmüyorum (Ö8)."

Bu katılımcı öğretmen ifadesi de standart testleri kültürümüze uymadıkları için kullanılmadığı görüşlerine örnektir. Çok zaman aldığı için uygulamadığını belirten bir öğretmen; “Onu tüm çocuklara uygulamak çok zaman. Testlerde çok fazla madde sayısı var. Tüm gelişim alanlarına ayrı ayrı bakıyor. MEB' de doldurulan bir sürü form oluyor. Her ay devamsızlık anne baba evlilik durumu gibi. Bu kadar çok evrak doldururken bir de öyle testleri tek tek çocuklara uygulamak mümkün değil (Ö11)." şeklinde görüşünü belirterek öğretmenlerin çocukların gelişimlerini takip etmeyi ilave bir yük gibi gördüklerini düşündürmektedir.

Katılımcı öğretmenler eğer aileler çocuklarına standart test uygulanmasını istemezse uygulamayacaklarını belirtmiştir. "Veliye bu testlerin neden uygulandığını açıklar, testlerin tamamen çocuğunun gelişimi için olumlu etkileri olacağı konusunda bilgi veririm. Çocuklarının olumlu ve olumsuz özelliklerini anlayıp, olumlu tarafları geliştirip, olumsuz tarafları da yok edebileceğimizi söylerim ama istemezse o çocuğa bir test uygulamam ve velinin istediğini anlayışla karşılarım(Ö4)." "Veli testin uygulanmasını istemezse dikkate alacağımı ancak herhangi bir soru durumunda, tanıma ve yardım etme kısmında sonuca ulaşılamayacağını belirtirim (Ö5)."

"Çocuğunun gelişimi için yararlı olabileceğini açıklarım. Testi direkt uygulamak bizim alanımızda hassas bir konu. Velinin bu talebini olumlu karşılarım. Çünkü belli gözlemleri sonucu çocuğunda herhangi bir alanda olumlu yönde bir farklılık hissetmesi onun çocuğu ile ilgili sürece aktif dahli olduğunu gösterir. Bu konu ile ilgili benim uygulayabileceğim bir test varsa uygularım. Yoksa bu konu ile ilgili hizmet veren bir birimden yardım alırım ya da veliyi yönlendiririm(Ö9)."

Yukarıda yer alan öğretmen ifadelerinden öğretmenlerin çocukların gelişimlerini takip etmek, standart testleri uygulamak konularında velilerinin düşüncelerine göre uygulama yaptıkları anlaşılmaktadır.

Katılımcı öğretmenlerden bazıları ise ailelerin çocukları için yazıyı bir değerlendirme istemediklerini onların da tepki almak istemedikleri için bunu yapmayacaklarını belirtmiştir. Örneğin katılımcı bir öğretmen; "Aile istemezse testi uygulamam. Tamam derim. Ona çocuğa olan katkısını anlatmaya çalışırım. Belli aralıklarla yapmam gerek derim. İstemezse de yapmam. Bir velim gelişim raporundan bahsedince bunu ne yapacaksınız dedi. Yıl sonunda portfolyo dosyasına koyup size göndereceğim dedim. Başka bir yere koyacak mısın dedi. "e-okul”a işleyeceğim dedim. İki üç cümlede olsa yazmam lazım zaten yapıyor değil desteğe ihtiyacı var yazıyorum dedim. İstemedi. Rapor alıp çocuklarının etiketleneceğini düşünüyorlar. Şiddet uygulayan bir çocuktu, davranış sorunuyla ilgili rapor alıp duyulacağı kaygısını yaşadı(Ö6)." ifadesiyle görüşünü belirtmiştir.

Yukarıda belirtilen ifadeler öğretmenlerin standart testlerin ne olduğunu, kullanım amacını ve kullanım şeklini bilmediklerini göstermektedir. 


\section{Bana Düşen Görev Nedir?}

Bulguların derinlemesine incelenmesiyle belirlenen; rehber öğretmen, çocuk gelişimi uzmanı, okul öncesi öğretmeninin sorumluluğu kodları "Bana düşen görev nedir?” teması başlığı altında toplanmıştır. Çalışmaya katılan öğretmenler şimdiye kadar sınıflarında özel gereksinimi olan çocukların olduğunu belirtmişlerdir. Örneğin; "Sınıfımda özel gereksinimli bir öğrencim oldu. Disleksi hastalığı vardı (Ö3). Zekâ Geriliği tanısı vardı (Ö5). Bireysel eğitim planı uyguladığım bir öğrencim vardı. Ancak RAM 'dan net bir tanı konulmamıştı (Ö9). Otizmli bir öğrencim oldu üç sene sınıfımdaydı (Ö12). Dikkat eksikliği ve hafif zekâ geriliği olan birer yıl öğrencilerim oldu(Ö10)." öğretmen ifadelerinden okul öncesi öğretmenlerinin sınıflarında sıklıkla özel gereksinimli çocukları olduğu görülmektedir.

Katılımcı öğretmenler gelişim testlerini bir eğitim öğretim döneminde dört kez uyguladıklarını, özel gereksinimli çocuklar içinde aynı değerlendirme yöntemini uyguladıklarını sadece özel gereksinimli çocuklara uygularken çok beklentiye girmediklerini belirtmişlerdir. "Üç ayda bir. Özel gereksinimli öğrenciler için farklı program olduğunu biliyorum ama farklı bir değerlendirme şekli var mı bilmiyorum. Belki onların değerlendirmeleri farklı kişiler tarafından yapılabilir (Ö6). Yılda üç dört kez uyguluyorum ben. Özel gereksinimli öğrencime de aynı testi yaptım ama disleksi hastası olduğu için dil gelişimi kısmını çok önemsemedim (Ö3). Öğrencilerin gelişimlerini belirli aylarda takip ediyorum. Eylül, Aralık, Nisan, Haziran (Ö10).” Bu görüşlerin yanı sıra belirli periyotlarla uygulanması gerektiğini düşünen ve ayda bir olmalı diyen öğretmen görüşleri de bulunmaktadır. Örneğin; "0-6 yaş grubunda çocukların gelişimleri her ay farklılık göstereceği için her ay uygulanmalıdır (Ö1). Belirli periyodlarla uygulanması ve takip edilmesi daha uygundur. Ancak fırsat eğitimi ilkesinden yola çıkılarak, gerekli görülen herhangi bir zamanda da uygulanabilir(Ö9). intiyaç duyulduğunda uygulanmalıdır (Ö4)."

Yukarıdaki ifadelerden yola çıkarak öğretmenlerin çocukların gelişimlerini takip süresiyle ilgili farklı görüşleri olsa da çoğunluğunun gelişim takip zamanıyla ilgili doğru bilgiye sahip olduğu söylenebilir.

Bununla birlikte katılımcı öğretmenler eğitim hedefleri ile gelişim değerlendirme arasındaki bağı kuvvetli olarak nitelendirmişlerdir. Örneğin; "Eğitim ve gelişim birlikte iç içedir. Çocukların gelişim düzeyine göre hedef belirlenir ve ona göre değerlendirilir (Ö1). Okul öncesinde ikisi arasındaki bağ son derece kuvvetlidir. Eğitim çocuğu geliştirmeyi hedefler. Öğretmen olarak ne istiyorum, şu an neredeyim bunu anlamamı sağlar. Değerlendirme bir kontrol mekanizmasıdır ve eğitimin olmazsa olmazıdır. Hedeflere süreç içerisinde eğitim öğretim durumlarının sonunda ne derece yaklaşıldı ve hangi kazanımlar elde edildi bunların mutlaka değerlendirilerek sonucuna bakılması gerekmektedir (Ö13). Gelişim değerlendirme yapılmazsa çocukların hazırbulunuşluk düzeyleri bilinemez. Hazırbuluşluklarına göre plan hazırlanıyor. Çocukların hangi aşamada oldukları belirlenip hedef belirleniyor haziran ayında da ne kadarına ulaşılmış o tespit ediliyor. (Ö10)." şeklinde öğretmen ifadeleri incelendiğinde eğitim hedefleri ve gelişim değerlendirme arasındaki bağ güçlü bulunduğu görülmektedir.

Katılımcı öğretmenlerin ifadelerinden yola çıkılarak, okullarda çocukların standart testlerle gelişim değerlendirmelerinin rehber öğretmenlerin ve çocuk gelişim uzmanları tarafından yapılmasının daha doğru olduğunu düşündükleri söylenebilir. Örneğin bir katıımcı öğretmen; "Standart testleri rehber öğretmen uygulamalıdır. Eğer çocuk gelişim uzmanı varsa onun uygulaması daha doğru olur (Ö2)." “Lisans eğitimi almış birisi standart testleri uygulamalı. Biz çok detaylı bilgi almadık ayrıca eğitim dışında becerisi ve deneyimi olan kişiler uygulamalı. Rehber öğretmen tarafından uygulanması daha doğru olacaktır (Ö7)". "Bu konuda uzmanlaşmış kişiler uygulamalı sınıf öğretmeni ve rehber öğretmenlerin uygulaması gerektiğini düşünüyorum(Ö9)." "Rehber öğretmenlerin uygulaması gerektiğini düşünüyorum. Keşke okullarda çocuk gelişimi uzmanı olsa, ama olmadığı için en azından şimdilik rehber öğretmen var o bu gelişim testlerini yapsa, velilerde daha ciddiye alır. Çocuk gelişim uzmanı yapsa daha da iyi veli uzman tarafından açıklanan bir sonucu daha ciddiye alacak ve bizimle ilişkisi zedelenmeyecektir(Ö10)." ifadelerinden öğretmenlerin lisansta almış oldukları eğitimi yeterli görmedikleri, rehber öğretmen ve çocuk gelişimi uzmanlarının daha yeterli olduklarını düşündükleri görülmektedir.

Yukarıdaki katılımcı öğretmen ifadelerinden yola çıkılarak öğretmenlerin özel gereksinimi olan çocukları belirlemede standart testleri kullanmadıkları, özel gereksinimi olan çocukların değerlendirilmesinin ne şekilde olacağını bilmedikleri, çocukların değerlendirmelerinin kendileri dışındaki uzmanlar tarafından yapılmasının daha uygun olduğunu düşündükleri söylenebilir.

\section{TARTIŞMA, SONUÇ VE ÖNERILER}

Okul öncesi öğretmenlerinin erken çocukluk döneminde uygulanan standart testlerle ilgili görüşlerinin incelendiği bu araştırmada, dört önemli sonuç ortaya çıkmıştır. Araştırma sonuçları ilk olarak, öğretmenlerin çocukların gelişimlerini takip etmek için daha çok gözlem yolunu tercih ettiklerini, çocukları değerlendirmeye yeterince zaman ayırmadıklarını, çocukları değerlendirmenin önemini tam olarak kavramadıklarını aynı zamanda nasıl takip edecekleri konusunda yeterli bilgiye sahip olmadıklarını ortaya koymaktadır. Bu nedenle, yüksek öğretim kurumlarında öğretmen yetiştirme programlarına kayıtlı öğretmen adaylarına çocukları değerlendirmeye yönelik yeterli bilgi, beceri ve deneyim kazandırmak çok önemlidir (Bennett ve Cunningham, 2009; Buck, Traut-Nare, Kaftan, 2010; Stiggins 2009; Carmona, Stroup ve Davis, 2006).

Okul öncesi öğretmenleri ile yapılan çalışmalar (Taner, 2005; Slentz, Early ve McKenna, 2008) bireyi tanıma tekniklerinden en çok görüşme ve gözlemi kullandıklarını ortaya koymaktadır. Okul öncesi öğretmen adayları da öğretmenlik uygulaması sürecinde zorlandıkları ya da kendilerini yetersiz gördükleri alanları, erken çocukluk dönemi yaş grubuna uygun olarak ölçme ve değerlendirmede zorlandıklarını ifade etmişlerdir (Karaman ve Karaman 2017). Değerlendirmenin önemi ve nasıl yapılması gerektiği araştırıldığında şu bilgilere ulaşılabilir; değerlendirme yöntem ve araçlarının ihtiyaçlara hitap edecek şekilde ve çocukların

| Kastamonu Eğitim Dergisi, 2020, Vol. 28, No. 61 
gelişimine katkı sağlayacak biçimde devamlı yenilenmesi, bütüncül bir yaklaşımla gözlemler yoluyla ve birebir çocuklarla çalışarak ebeveynlerin ve öğretmenlerin de değerlendirme sürecinin içinde yer aldığı, standardize edilmiş materyalleri olan ölçme araçlarının geliştirilmesi ya da geçerlik güvenirliliği ispatlanmış ölçme araçlarının kültürlere uygun şekilde geliştirilmesi gereklidir (Tunçeli ve Zembat, 2017).

Öğretmenlerin zorluk yaşamadan değerlendirme yaptıklarını, tüm öğretmenlerin günlük plan oluşturduğu ve değerlendirme yaparken çocuk, program ve öğretmen açısından ele alarak değerlendirme yaptıkları görülmüştür. Öğretmenler tarafından çocuklarla ilgili bilgilerin kayıt altına alındığı, çocukları tanıma ve değerlendirme sürecinde elde edilen bilgilerin ailelerle paylaşıldığı ancak yeterli düzeyde bir paylaşım olmadığı sonucuna ulaşılmıştır (Parlakyıldız ve Yıldızbaş, 2007). Ancak bazı araştırmalar öğretmenlerin değerlendirme araçlarını uygularken farklı zorluklar yaşadıklarını göstermiştir (Buldu, 2010; Kang, 2013; Kroeger ve Cardy, 2006).

Öğretmenlerin program değerlendirmeye yönelik olumlu görüşleri vardır (Can Gül, 2009). Öğretmenler tarafından, eğitimin etkililiği için değerlendirmenin gerekli olduğu, gelişim kontrol listelerinin, portfolyoların, anekdot kayıtlarının, yıllık ve günlük planların değerlendirme bölümlerinin doldurulması gerektiğine inandıkları söylenmiştir. Erken çocuklukta değerlendirme, çocukları anlayabilmek için gerçekleştirilen standart testleri, gözlemi, aile öğretmen görüşmelerini, çalışma örneklerini, kayıtları ve çevresel faktörleri içeren bilgi toplama işlemidir (Brassard ve Boehm, 2007).

İkinci olarak, bu araştırma sonucunda standart testlerin kullanımının özel bir eğitim ve uzmanlık gerektirmesi nedeniyle, öğretmenler tarafından kullanılmayı tercih etmedikleri görülmüştür. Oysaki standart testlerin uygulanmasında testi dışarıdan gelecek biri yapsa dahi asıl sorumlu, birincil değerlendiricinin öğretmen olması ve testin yapay durumlarla değil zaten sınıf içinde yapılan etkinliklere dayalı olması gerekir (Beaty, 2018). Öğretmenlerin standart testlerden bazılarının isimlerini bildikleri fakat standart testin ne olduğunu, hangi amaçla kullanıldığını tam olarak bilmedikleri saptanmıştır. Küçük çocuklarla çalışan bir dizi profesyonel, bu popülasyonla standartlaştırılmış testlerin kullanılmasından rahatsızlık duymaktadır (Lidz, 2003).

Bazı araştırmacılar söz konusu standart testlere karşı çıkmakla birlikte, öncelikli olarak erken müdahaleyi savunurlar. Testlerin zekâ kavramını farklı ele aldıklarını ve çocukların zekalarını ölçme aracı gibi yanlış kullanıldığını düşünmektedirler (Neisworth ve Bagnato, 1992). Düşek (2008) yapmış olduğu çalışmada okul öncesi öğretmenlerinin değerlendirme sürecinde kullanmaları gereken formlarla ilgili öğretmenlerin doldurulacak formların benzer nitelikte olması programın uygulanmasını güçleştiren etmenler içerisinde yer verdikleri görülmüştür. Öte yandan, Cömert (2003) ve Demir'in (2001) araştırmalarında öğretmenlerin değerlendirmeye yönelik araçların kullanımında yetersiz ve isteksiz oldukları ifade edilmiştir.

Araştırma sonucuna göre öğretmenlerin çocukların gelişimlerini takip süresiyle ilgili farklı görüşleri olsa da çoğunluğunun gelişim takip zamanıyla ilgili doğru bilgiye sahip olduğu söylenebilir. Değerlendirmenin etkili olabilmesi için belirli zaman aralıklarında uygulanması, öğretim ve öğrenme hakkında geri bildirim verilmesi ve öğrenme hedeflerinin açıkça belirlenmesi ayrıca bu hedeflerin bir sürece yayılması gereklidir (Qu ve Zhang, 2013).

Bu çalışma sonucunda öğretmenlerin çocukların gelişimlerini takip etmek, standart testleri uygulamak konularında velilerinin düşüncelerine göre hareket ettikleri ve veliler testlerin uygulanmasını istemezse uygulanma yapmayacaklarını anlaşılmaktadır. Değerlendirme sürecine aileler dahil edilirse, öğretmenlerin işinin kolaylaşacağı düşünülmektedir. Ailelerin değerlendirme sürecinde yer almasının gerektiği (Can Gül, 2009; Buldu, 2010; Hanes, 2009) yapılan çalışmalarla ortaya koyulmuştur.

Araştırmanın ortaya koyduğu üçüncü bulgu, özel gereksinimi olan çocukların tespiti için standart testlerden faydalanılmadığıdır. Özel gereksinimi olan öğrencilerin değerlendirilmesinin ne şekilde olacağının öğretmenler tarafından bilmemesi, öğrencilerinin standart testlerle gelişim değerlendirmelerini yapmakta kendilerini yetkin görmemeleri de araştırmanın sonuçları arasındadır. Öğretmenler tarafından yapılan gözlemler, çocukta bir farklılık olduğunu gösteriyor ise öğretmenler acele etmeli, çocuk için programda uyarlama ve düzenleme çalışmaları yapmalıdır. Bazı çocuklar öğretmenlerin yapacağı bu değişikler ile yaşıtlarını gelişimsel olarak yakalayabilirler fakat yapılan tüm değişikliklere rağmen yetersizlik riski olduğu düşünülen bir çocuğun ayrıntılı incelenerek tanı konulması gerekir. Tanı konulması ise çocuk il veya ilçelerdeki rehberlik araştırma merkezlerine yöneltme raporu ile gönderilir. Yöneltme raporunu gönderen öğretmen ayrıntılı gözlem sonuçlarının yanı sıra, standart testlerden elde ettiği bulguların sonuçlarını da mutlaka söz konusu rapora eklemelidir. Bu çalışma öğretmenlerin özel gereksinimli çocukların belirlenmesi için ne yapmaları gerektiği hakkında bilgi sahibi olmadıklarını ve sadece gözlem tekniğini kullandıkları için değerlendirme basamağını eksik bıraktıklarını göstermiştir.

Özetle, bu araştırmanın sonuçları öğretmenlerin gelişimsel değerlendirmeye yeterince vakit ayırmadıklarının bunun bilgi eksikliğinden kaynaklandığını göstermiştir. Bu nedenle araştırma sonuçları ışığında, öğretmenlere değerlendirme konusunda eğitim verilmesi önerilmektedir. Farklı gelişim değerlendirme yöntemlerinin bir arada kullanılması, özellikle özel gereksinimli çocukların belirlenmesinde önemli katkılar sunmaktadır. Özel gereksinimli çocukların belirlenmesinde izlemeleri gereken yollar konusunda bilinçlendirilmeleri önerilmektedir. Çünkü özel gereksinimli çocukların eğitiminde, ayrıntılı bir değerlendirmenin çok önemli bir yeri vardır. Özel gereksinimli çocuklar ayrıntılı değerlendirildiklerinde öğrenmeye gereksinim duydukları beceri ve davranışlar belirlenebilecek ve bu davranışların onlara öğretilmesine odaklanılacaktır. Böylece öğretimde geçen zamanları en iyi biçimde kullanılabilecek, öğrendikleri beceri ve davranışlar, onların yaşama uyum sağlamalarını kolaylaştıracaktır. Bunu sağlamak için, okul öncesi eğitim kurumlarında, gelişim değerlendirmenin önemi ve standart testler hakkında öğretmenlere bilgi verilebilir. Ayrıca uzmanlar tarafından konuya ilişkin videolar kaydedilip çevrimiçi ortamlarda yayınlanabilir. Bu yollarla öğretmenlere çocukların düzenli gelişimsel değerlendirmelerinin yapılmasının gerekliliği anlatılmalıdır. 
Bu araştırma önemli bulgular ortaya koymakla beraber bazı sınırlıklarını dikkate alarak sonuçları yorumlanmalıdır. İlk olarak, araştırmaya katılan çalışma grubu, Denizli ilinde görev yapan öğretmenlerden oluşmaktadır. Bu araştırmada 15 okul öncesi öğretmeni görüşme yapmayı kabul etmiştir. Katılımcı öğretmenlerin tamamı herhangi bir standart test eğitimi almamış öğretmenlerdir. Bu nedenle bu katılımcılardan elde edilen sonuçların tüm öğretmenler için genelleme yapılması oldukça güçtür. Bundan sonra yapılacak araştırmalarda daha büyük örneklem grubu ve tek bir standart test eğitimi almış bile olsa, eğitim geçmişi olan öğretmenlerin de dahil edilerek incelenmesi yararlı olacaktır. Ayrıca, araştırmanın örnekleminin sadece okul öncesi öğretmenlerden oluşmaması ve çocuk gelişimi mezunu veya rehberlik ve psikolojik araştırma mezunu olup çocuklarla çalışan profesyoneller arasında karşılaştırılmalı bir araştırılmanın yapılmasına acil bir ihtiyaç olduğu düşünülmektedir.

\section{KAYNAKÇA}

Ay, H. (2015). Eğitim fakültesi ilköğretim bölümünde derslerin işleniş ve ölçme değerlendirme sürecine ilişkin öğretmen adaylarının görüşlerinin incelenmesi. Yayınlanmamış Yüksek Lisans Tezi. Fırat Üniversitesi, Eğitim Bilimleri Enstitüsü, Elâzı̆̆.

Beaty, J. J. (2018). Erken çocuklukta gözlem ve değerlendirme. (Menekşe Boz, Çev.). Ankara: Anı Yayıncılık.

Bennett, K.R., \& Cunningham, A.C. (2009). Teaching formative assessment strategies to preservice teachers. Journal of Computing in Teacher Education, 25(3), 99-105.

Blake, B.S. \& Wise, L.L. (2014). What Is the Role and Importance of the Revised AERA, APA, NCME Standards for Educational and Psychological Testing?. Educational Measurement: Issues and Practice, 33(4), 4-12.

Bondurant-Utz, J., \& Luciano, L. B. (1994). A practical guide to infant and preschool assessment in special education. Boston: Allyn and Bacon.

Brassard, M. ve Boehm, A. (2007). Preschool assessment: Principles and practices. Guilford Publications.

Bredekamp, S. (2015). Erken çocukluk eğitiminde etkili uygulamalar. (Effective Practices in Early Childhood Education, 2nd Edition). (Çev. Hatice Zeynep İnan ve Taşkın İnan). 343-345. Ankara: Nobel Yayıncılık.

Buck, G. A., Trauth-Nare, A., \& Kaftan, J. (2010). Making formative assessment discernable to preservice teachers of science. Journal of Research in Science Teaching, 47(4), 402-21.

Buldu, M. (2010). Do they walk the talk: An examination of Turkish in-service early chilhood teachers' assessment practices. Unpublished Master's Thesis, Middle East Technical University, Ankara.

Can Gül, Ş. (2009). Okul öncesi eğitimi öğretmen ve öğretmen adaylarının 2006 okul öncesi eğitim programının değerlendirme unsuruna yönelik görüş ve davranışlarının incelenmesi. Yayınlanmamış Yüksek Lisans Tezi. Pamukkale Üniversitesi. Sosyal Bilimler Enstitüsü, Denizli.

Carmona, G., Stroup, W., \& Davis, S. (2006). Introducing preservice teachers to formative assessment: Improving assessment design and accountability in school mathematics through a network-based learning environment. Proceedings of the 28th Annual Meeting of the North American Chapter of the International Group of the Psychology of Mathematics Education, Universidad Pedagogica Nacional, Meridia, Mexico.

Cohen, L., Manion, L., \& Morrison, K. (2007). Research methods in education (6th ed.). New York, NY: Routledge.

Cömert, S. (2003). 2002 yılı okulöncesi eğitim programı hakkında öğretmen görüşleri ve uygulamaları (Sakarya ili Örneği). Yayınlanmamış Yüksek Lisans Tezi, Sakarya Üniversitesi Sosyal Bilimler Enstitüsü, Sakarya.

Crain, S., \& Lillo Martin, D. (1999). An Introduction to linguistic theory and language acquisition. USA: Blackwell Publishers.

Çakan, M. (2004). Öğretmenlerin ölçme-değerlendirme uygulamaları ve yeterlik düzeyleri: Illk ve ortaöğretim. Ankara University, Journal of Faculty of Educational Sciences, 37(2), 99-114.

Davies, D. (2010). Child Development: A practitioner's guide (Social Work Practice With Children and Families). New York: The Guilford Press.

Demir, Ö. (2001). Anasınıfı programının öğretmen görüşleri çerçevesinde değerlendirilmesi. Yayınlanmamış Yüksek Lisans Tezi, Atatürk Üniversitesi Sosyal Bilimler Enstitüsü, Erzurum.

Demircan, H. Ö. \& Olgan, R. (2011). Assessment in early childhood education: Commonly used curriculum models and Turkish curriculum. The Online Journal Of New Horizons In Education, 1(3), 16-22.

Demirci, A. \& Kartal, M. (2012). Çocukluk dönemine ait bir sorun: Gelişme geriliği ve erken tanının önemi, Turkish Family Physician,

3(4), 1-6.

Demirli, C. (2007). E-Portfolyo öğretim sürecinin öğrencilerin tutumları ve algıları üzerine etkisi. Yayınlanmamış Doktora Tezi, Fırat Üniversitesi, Sosyal Bilimler Enstitüsü, Elâzığ.

Deniz Kan, Ü. (2007). Okul öncesi eğitimde değerlendirme aracı olarak portfolyo. GÜ, Gazi Eğitim Fakültesi Dergisi, 27(1), 169-178.

Diffily, D. L. (1994). Early childhood educators' beliefs and practices about assessment. Unpublished Doctoral Dissertation. University of North Texas.

Düşek, G. (2008). 2006 Yılında uygulamaya konulan okul öncesi eğitim programı hakkında ilköğretim müfettişleri, okul öncesi eğitim veren kurum müdürleri ve okul öncesi öğretmenlerinin görüşlerinin incelenmesi (Ordu ilii Örneği). Yayınlanmamış Yüksek Lisans Tezi, Selçuk Üniversitesi Sosyal Bilimler Eğitim Bilimleri Enstitüsü, Konya.

Erdemir, Z. A. (2007). Illköğretim ikinci kademe öğretmenlerinin ölçme değerlendirme tekniklerini etkin kullanabilme yeterliklerinin araştırılması. Yayımlanmamı yüksek lisans tezi. Kahramanmaraş Sütçü İmam Üniversitesi Sosyal Bilimler Enstitüsü, Kahramanmaraş.

George, T. I. (2012). Early childhood teachers' views on working with parents: positive and negative encounters in maintaining the home/school relationship in high/low income schools. Unpublished Doctoral Dissertation. Kent State University. 
Gullo, D.F. (2006). Alternative means of assessing children's learning in early childhood classrooms. (Ed. B. Spodek ve O.N. Saracho) Handbook of Research on the Education of Young Children (s.443-455). New Jersey: Lawrence Erlbaum Associates.

Hanes, B. M. (2009). Perceptions of early childhood assessment among early childhood educators. Unpublished Doctoral Dissertation. Widener University.

ışık, H. (2007). Okul öncesi eğitim kurumlarında gerçekleştirilen okul-aile iş birliği çalışmalarının anne-baba görüşlerine dayalı olarak incelenmesi. Yayımlanmamış Yüksek Lisans Tezi. Anadolu Üniversitesi, Eğitim Bilimleri Enstitüsü, Eskişehir.

Işıkoğlu Erdoğan, N. \& Canbeldek, M. (2017). Erken Çocukluk Eğitiminde Ölçme ve Değerlendirme. Abant Izzet Baysal Üniversitesi Eğitim Fakültesi Dergisi, 17(3), 1306-1327.

Kahraman, Ö.G., Ceylan, Ş. \& Korkmaz, E. (2016). 0-3 yaş arası çocukların gelişimsel değerlendirmelerinin bazı değişkenler açısından incelenmesi. Mersin Üniversitesi Sağlık Bilim Dergisi, 9(2), 60.

Kang, J. (2013). Thoughtful early childhood teachers: Documentation as part of teaching. Unpublished Doctoral Dissertation. University of Illinois.

Karaaslan, T., (2016). Gelişimin değerlendirilmesi, izlenmesi ve desteklenmesinde klinik ve iletişim beceri eğitimi neden gereklidir?. Inönü Üniversitesi Sağlık Hizmetleri Meslek Yüksekokulu Dergisi, 4(2).

Karaman, P. \& Karaman, A. (2017). Öğretmen adaylarının Biçimlendirici Değerlendirme Uygulamalarının İncelenmesi: Eylem Araştırması Modeli. Kastamonu Eğitim Dergisi, 25(6), 2385-2400.

Kılıç, S. (2013). Örnekleme yöntemleri. (Turkish). Journal of Mood Disorders, 3. 44-46.

Kroeger, J., \& Cardy, T. (2006). Documentation: A hard-to-reach place. Early Childhood Education Journal, 33, 389-98.

Lidz, C. S. (2003). Early Childhood Assessment. New Jersey: John Wiley \& Sons, Inc., Hoboken.

Madan, R., \& Tekin, D. (2015). "0-6 Yaş grubu çocukların gelişim takipleri" programı. Hacettepe University Faculty of Health Sciences Journal, 1.

Mcafee, O. \& Leong, D. J. (2012). Erken çocukluk döneminde gelişim ve öğrenmenin değerlendirilmesi ve desteklenmesi. (Birsen Ekinci, Çev.). Ankara: Nobel Yayıncilık.

Mehlig, L. M. (2013). Preparing preservice teachers to engage parents through assessment. Unpublished Doctoral Dissertation. Northern Illinois University.

Merriam, S. B. (2015). Nitel araştırma: Desen ve uygulama için bir rehber. (Selahattin Turan, Çev.). Ankara: Nobel Yayıncılık.

Miles, M, B., \& Huberman, A. M. (1994). Qualitative data analysis: An expanded Sourcebook. (2nd ed). Thousand Oaks, CA: Sage.

Mindes, G. (2007). Assessing young children. New Jersey: Pearson Merrill Prentice Hall.

Neisworth, J. T. \& Bagnato, S. J. (1992). The case against intelligence testing in early intervention. Topics in Early Childhood Special Education, $12,1-20$.

Önder, A. (2016). Okul öncesi dönemde çocukları tanıma ve tanıma teknikleri. Ankara: Pegem Akademi.

Özkan, F. (2015). Okul öncesi eğitimde değerlendirme sürecine yönelik aile-öğretmen görüş ve beklentilerinin incelenmesi. Yayınlanmamış Yüksek Lisans Tezi, Hacettepe Üniversitesi Eğitim Bilimleri Enstitüsü, Ankara.

Parlakyıldız, B. \& Yıldızbaş, F. (2007). Okulöncesi öğretmenlerinin 2006 programını değerlendirme sürecindeki performanslarının incelenmesi, (Ed. Ergin Erginer) XVI. Ulusal Eğitim Bilimleri Kongresi Tam Metinler, 2, 376 - 381. Detay Yayıncılık: Ankara.

Patton, M.Q. (2002). Qualitative research and assessment methods (3rd Ed.). London: Sage Publications, Inc.

Qu, W. \& Zhang, C. (2013). The analysis of summative assessment and formative assessment and their roles in college English assessment system. Journal of Language Teaching and Research, 4(2), 335-339.

Sezer, C. (2010). Okul öncesi öğretmenlerinin ölçme değerlendirmeyi kullanma düzeylerinin belirlenmesi. Yayınlanmamış Yüksek Lisans Tezi. Çanakkale Onsekiz Mart Üniversitesi, Sosyal Bilimler Enstitüsü, Çanakkale.

Slentz, K. L., Early, D. M. \& Mckenna, M. (2008). A guide to assessment in early childhood Infancy to age eight. Washington State Office of Superintendent of Public Instruction.

Stiggins, R. (2009). Essential formative assessment competencies for teachers and school leaders. In H. L. Andrade \& G. Cizek (Eds.), Handbook of formative assessment (pp. 233-50). New York: Routledge.

Stone, B. J. (1995). Best practices in the use of standardized assessments. In A. Thomas \& J. Grimes (Eds.), Best practices in school psychologyIII. Washington, DC: National Association of School Psychologists.

Sıvgın, N. (2005). Okul öncesi eğitim kurumlarında uygulanan eğitim programına ilişkin öğretmen görüşleri: Denizli ili örneği. Yüksek Lisans Tezi. Pamukkale Üniversitesi Sosyal Bilimler Enstitüsü, Denizli.

Taner, G. (2005). Bireyi tanıma tekniklerinin okul öncesi eğitim kurumlarında uygulanmasına ilişkin öğretmen görüşleri. Yayımlanmamış Yüksek Lisans Tezi. Selçuk Üniversitesi, Sosyal Bilimler Enstitüsü, Konya.

Tavşancıl, E. \& Asalan E. (2001). İçerik analizi ve uygulama örnekleri. İstanbul: Epsilon Yayınları.

Tuğrul, B. (2005). Çocuğu tanıma ve değerlendirme. M. Sevinç (Yay. Haz.). Gelişim ve Eğitimde Yeni Yaklaşımlar, 2, 380-392. İstanbul: Morpa Kültür Yayınları.

Tunçeli, H. İ. \& Zembat, R. (2017). Erken çocukluk döneminde gelişimin değerlendirilmesi ve önemi. Eğitim Kuram ve Uygulama Araştırmaları Dergisi, 3(3), 01-12.

UNICEF (2003). The State Of The World's Chıldren 2003. Erişim Tarihi: 26.04.2016. https://www.unicef.org/sowc03/contents/pdf/ sowc03eng.pdf.

Yıldırım, A. \& Şimşek, H. (2006). Sosyal bilimlerde nitel araştırma yöntemleri. 6. Baskı. Ankara: Seçkin Yayıncılık. 
Yılmaz Topuz, G. (2015). Okulöncesi eğitim öğretmenlerinin çocukları tanıma ve değerlendirme amaçlı yapılan çalışmalara iliş̧in görüşleri. Yayımlanmamış Yüksek Lisans Tezi. Anadolu Üniversitesi Eğitim Bilimleri Enstitüsü, Eskişehir.

Yiğit, C, Özyurt, M. \& Adıyaman, H. (2019). Okul öncesi öğrencilerinin programın kazanımlarına ulaşma durumlarının değerlendirilmesine ilişkin bir model önerisi. Eğitimde Kuram ve Uygulama, 15(3), 237-252. DOI: 10.17244/eku.444573

Zehir Topkaya, E. (2006). Sosyal bilimlerde nitel araştırma yöntemleri (Yıldırım, A. ve H. Şimşek). Eğitimde Kuram ve Uygulama, 2(2), 113-118. 